\title{
Environmental impact assessment of rail freight intermodality
}

\author{
Angel L. MERCHAN ${ }^{1}$ \\ Sandra BELBOOM ${ }^{I}$ \\ Angélique LEONARD ${ }^{1}$
}

\begin{abstract}
The European Commission's White Paper on transport (European Commission, 2011) seeks to achieve an efficient and sustainable balance between the various transport modes. Environmental impact studies on intermodality transport show that rail freight transport is the land-based transport that has a higher environmental performance compared to intermodal road-rail and all-road transport (Fries and Hellweg, 2014), especially when electrified railway is used (Spielmann and Scholz, 2005). Life Cycle Assessment (LCA) methodology allows us to model as best as possible the environmental impacts of several pollutants in numerous categories. For other categories such as accident damages, noise impact and land use, new developments have to be performed. For the environmental impact assessment, all life cycle phases of rail freight transport operation, rail infrastructure, and rail equipment are taken into account (Spielmann et al., 2007).
\end{abstract}

Keywords: environmental impact, rail freight, intermodality transport.

\section{Introduction}

The European Commission's White Paper on transport enumerates 10 strategic goals that aim to increase the rail market share. The goal 3 states: " $30 \%$ of road freight over $300 \mathrm{~km}$ should shift to other modes such as rail or waterborne transport by 2030 , and more than $50 \%$ by 2050, facilitated by efficient and green freight corridors" (European Commission, 2011).

The modal shift from road transport to rail freight intermodality promoted by the European Union's transportation policy aims at reducing the environmental impact of freight transport, both by reducing pollution and improving road safety (Crozet et al., 2014). It can also contribute to transport energy efficiency and cost-effectiveness by higher carrying capacities (Lammgård, 2012).

Although rail freight share in Belgium has grown since 2009 (EUROSTAT, 2015), the road transport is still the dominant mode. Looking at the last available statistical data on freight transport in EUROSTAT, the modal split of freight transport (percentage in total inland freight expressed in tonne-kilometres) in 2012 to Belgium are a modal share for rail freight of $17.5 \%, 24.3 \%$ of inland waterways and $58.3 \%$ of road transport (EUROSTAT, 2015).

The rail freight transport in Belgium does not have a prominent position compared to other European countries (Van de Voorde and Vanelslander, 2014), despite the fact that Belgium meets the conditions for improving the development of the rail freight transport, such as presenting a high density of rail network (117 km of rail line per $1000 \mathrm{~km}^{2}$ in 2012) and having the second freight traffic European Union seaport (Port of Antwerp) with 164,546 million of tonnes in 2012 (EUROSTAT, 2015).

A major opportunity of the rail freight transport is to replace road transport in journeys longer than $300 \mathrm{~km}$ (European Commission, 2011), but despite the fact that rail transport is more energy efficient (more fuel-efficient shipping alternative (Hendrikson et al., 2006)), road transport is more flexible, causing its dominant use (Demir et al., 2015). There is not always a direct rail link, so the intermodal road-rail transport is generally shown as the best alternative.

\footnotetext{
${ }^{1}$ Department of Chemical Engineering, Products, Environment, Processes (PEPs), University of Liege, Belgium
} 
The rail could also complete the offer of the air and sea freight transport. However, two obstacles need to be addressed: on one hand, trains need to be more performant (longer, higher speeds and larger axle loads), and on the other hand, congestion bottlenecks due to the use of the same track for passenger and freight trains have to be eliminated. In order to overcome the technical problems derived from these two challenges, an investment is required (European Parliament, 2010).

In Belgium, the transport sector is the main source of greenhouse gas emissions. Including emissions from international transport (see figure 1), the transport sector constitutes $34.64 \%$ of total emissions. Almost half of the transportation emissions are caused by road transport (49.69\%), assuming only $0.21 \%$ rail transport.

Figure 1 : Greenhouse gas emissions $\left(\mathrm{CO}_{2}, \mathrm{CH}_{4}, \mathrm{~N}_{2} \mathrm{O}, \mathrm{SF}_{6}, \mathrm{HFC}\right.$ and $\left.\mathrm{PFC}\right)$ by sector and mode of transport in Belgium in 2012, including international bunkers emissions but excluding LULUCF (Land Use, Land-Use Change and Forestry) emissions. Source: Own elaboration based on EUROSTAT data (European Commission, 2014)

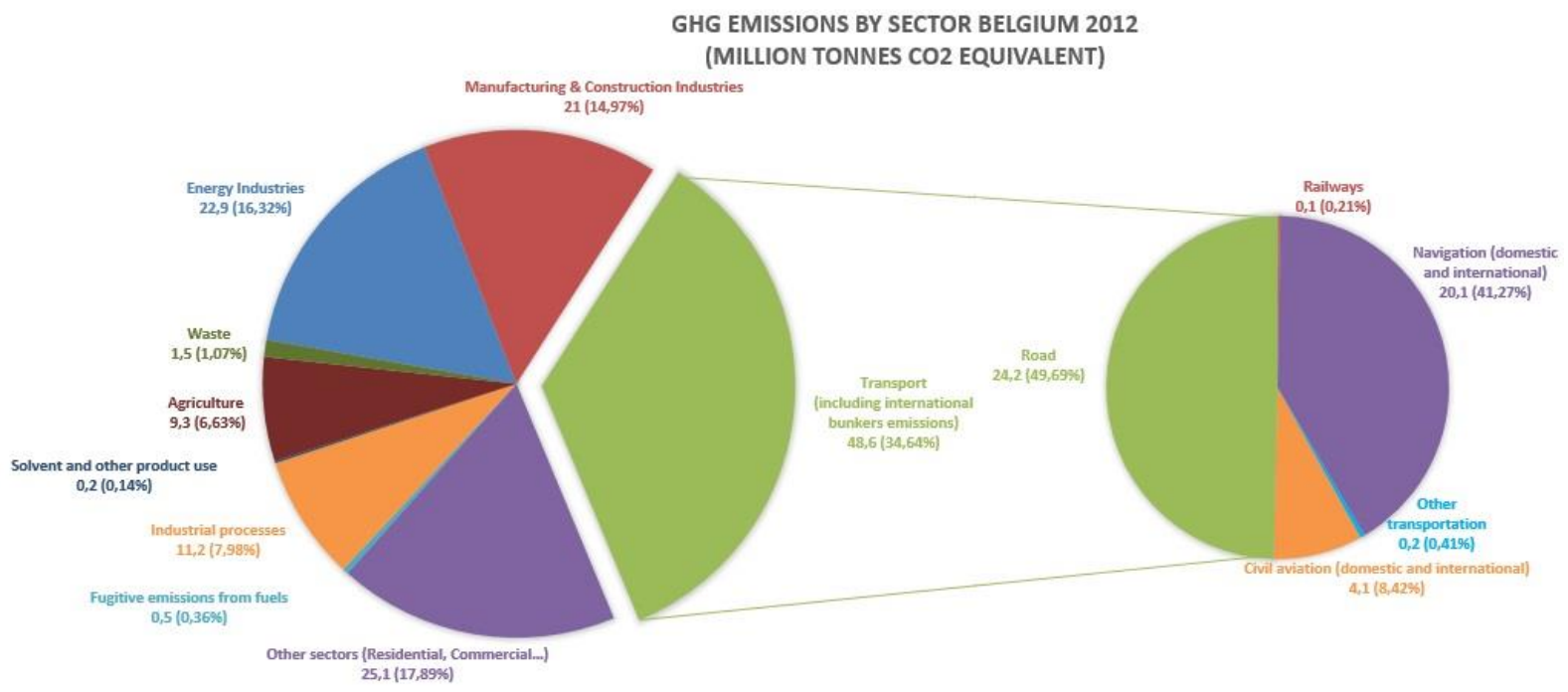

BRAIN-TRAINS is a project supported by the Belgian Federal Government that deals with rail freight intermodality, approaching the problem from an interdisciplinary perspective. The purpose of this paper is to explain how the project BRAIN-TRAINS aims at determining the environmental impact of the rail freight intermodality for several Belgian scenarios using the Life Cycle Assessment (LCA) methodology. This requires namely to have Belgian specific data that are missing nowadays.

\section{Methodology}

To analyse the sustainability impact of rail freight intermodality in Belgium, the Life Cycle Assessment (LCA) methodology will be used. LCA methodology is standardised by ISO Standards 14040 and 14044 (International Standardization Organization, 2006), being also used in Europe the ILCD Handbook (European Commission, 2010 and European Commission, 2011) as a reference to perform an LCA.

The LCA methodology allows us to study complex systems like intermodal transport providing a system perspective analysis that allows to assess environmental impacts through all the stages of rail freight system (rail operation, rail equipment and rail infrastructure), from raw material extraction, through material's use to disposal. The continuous development and improvement of this methodology allows it to be up-to-date and to be a reference to model in a quantitative and multi-criteria way the environmental impacts of several pollutants in numerous categories of the railway freight intermodality. 
Commercial databases as Ecoinvent (Weidema et al., 2013) have been developed to allow an easier access to the inventory of numerous processes (e.g. transportation of one ton over one $\mathrm{km}$ by lorry). The existing databases allow us to perform a preliminary search to guide us in identifying the most influential factors in the environmental impact of freight transport (Spielmann and Scholz, 2005). Once these are identified, we may collect the most significant data, and develop a new database of rail freight transport in Belgium. After collecting the data, we will make a comparison of our results with the already existing and this will give us clues about how to improve the environmental performance of the rail freight transport.

Even if generic commercial databases are available, there are no Belgian specific commercial transportation databases and current databases should be improved and updated. One of the aims of the study is to develop a transportation database specific to Belgium to allow a better modelling of the obtained environmental impacts and to improve the specificity of the results. We will take as a model the Swiss transport database included in Ecoinvent database, which is the most comprehensive transport database available. One thing to take into consideration is that the rail freight transport in Switzerland is mainly done with electric traction which is not the case in Belgium where a combination with diesel traction appears (Spielmann et al., 2007).

The UNEP/SETAC Life Cycle Initiative "Global Guidance Principles for Life Cycle Assessment Databases" (UNEP/SETAC, 2011) and the general guidance and data collection sheets in ISO 14040 and ISO 14044 (International Standardization Organization, 2006) provide guidance to develop a new unit process dataset and they explain how to document the procedures in a structured way. The existing literature will be also taken into account, as well as the valid Product Category Rules (PCR) for railways (The International EPD® System, 2014) and the available Environmental Product Declarations (EPD).

Currently, there is no publication relative to the state-of-the-art for Belgian freight transportation and technical data (machine type, tracks, capacity, energy supply, etc.), having a lack of data for the assessment of transportation impacts and concerning building infrastructure. For data collection, more reliable sources of information will be identified and we will proceed to the drafting of questionnaires for the collection of information through interviews with different stakeholders (transport sector members, vehicle manufacturers, freight operators and project partners).

LCA studies demonstrate the importance of all life-cycle phases (infrastructure and vehicle life cycle) and not only the modelling of fuel combustion for the assessment of transport. The pre-combustion processes will become even more important than direct emission due to the introduction of new engines and emission reduction technologies (Facanha and Horvath, 2006; Spielmann and Scholz, 2005).

The European TEN-T program (Trans-European Transport Network) plans to develop three corridors in Belgium, which could cause an increase in the demand for rail transportation and an expansion of the railroad network (European Commission, 2014b). The expansion of the railroad system and the environmental effects that infrastructure construction entails should be taken into account (Spielmann et al., 2007).

The rail freight system is divided in this study in direct processes (rail operation) and indirect processes (rail equipment and rail infrastructure). As shown in figure 2, all life cycle phases of rail freight transport operation, rail infrastructure (construction, maintenance and disposal), and rail equipment (manufacturing, maintenance and disposal) are taken into account (Spielmann et al., 2007). 
Figure 2 : System boundary of the study. Source: Own elaboration based on Spielmann et al., 2007; The SMARTrail Consortium, 2014 and Stripple and Uppenberg, 2010

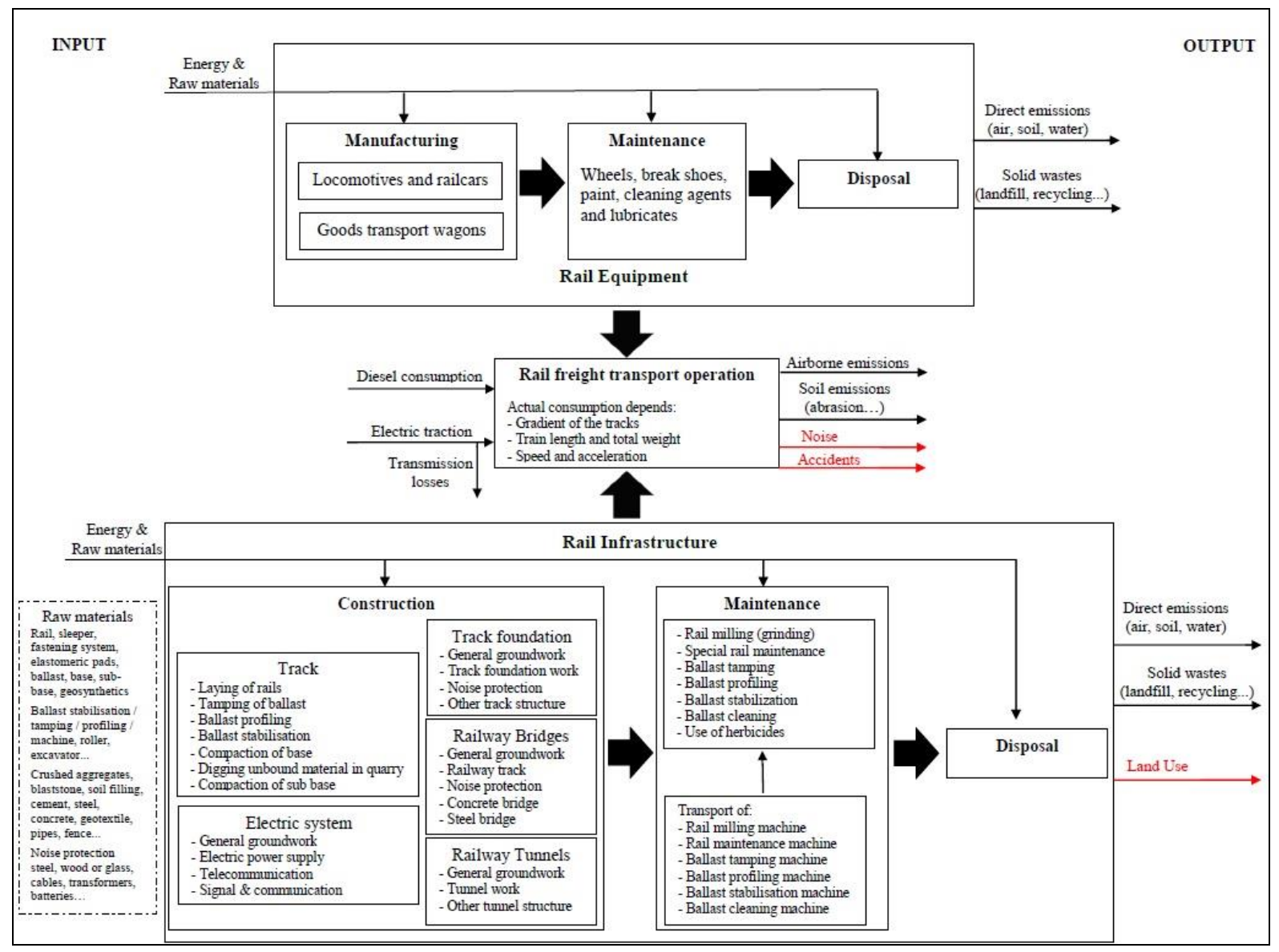

\subsection{Life cycle Inventory for rail operation}

Rail operation stage are the processes that are directly connected with the operation of trains including the energy consumption per train (share of diesel and electricity traction) and the direct emissions to air from diesel combustion $\left(\mathrm{CO}_{2}, \mathrm{CO}\right.$, NOx, SOx, NMVOC and particles emissions) or from electricity consumption (SF6 emitted during conversion at traction substations) and direct emission to soil of iron due to abrasion from braking (rail tracks, wheels and brakes) and lining (overhead contact line) (Spielmann et al., 2007).

There are 13 rail freight operators and traction companies in Belgium, which could lead to some difficulties to obtain consolidated data regarding rail operation and equipment. In 2012, SNCB Logistics (the public company of freight transport) market share was $86.62 \%$ of tkm (Van de Voorde and Vanelslander, 2014), which should facilitate the collection of representative data.

Rail freight transport consumes much energy, being the source of this energy one of the key factors for rail sustainable transport (Reis et al., 2013). Rail transport is gradually changing the use of diesel engines for electricity power (EEA, 2008). Moreover, using electrical energy coming from renewable sources would be one of the main opportunities for improvement (McKinnon et al., 2015).

The Benelux countries registered the highest share of electrified network in the European Union in 2012, with $95.3 \%$ of length of lines in use electrified in Luxembourg, $85.5 \%$ in Belgium (3064 km of $3582 \mathrm{~km}$ ) and $72.2 \%$ in Netherlands. The only European country with $100 \%$ of electrified network is Switzerland (European Commission, 2014). 


\subsection{Life Cycle Inventory for rail equipment}

Rail equipment stage includes the processes that are connected with the vehicle life cycle (locomotives and rail wagons, excluding the operation) currently used such as manufacturing, maintenance (e.g. consumption on wheels, break shoes, paint, cleaning agents, lubricates, etc. and waste process) and disposal (Spielmann et al., 2007). Belgium has a stock of 1266 locomotives and railcars and 11612 goods transport wagons (European Commission, 2014).

\subsection{Life Cycle Inventory for rail infrastructure}

To facilitate the data collection, the rail infrastructure stage has been divided into four parts: railway track system (railway track and railway track foundation), railway bridges, railway tunnels and railway electrical equipment (electric power supply, telecommunication and signal and communication). For all parts, the construction, maintenance and finally disposal is taken into account (Spielmann et al., 2007).

In order to make the rail infrastructure system more understandable, each of the four parts is divided in turn into different stages (see table 1). In each stage (except general groundwork stage) we analyse its characteristics, transport to the place of construction of the track, railway bridge or railway tunnel, the construction works related to each stage, the maintenance works (included the transport of new material and machines) and the end of life of each material (The SMARTrail Consortium, 2014).

Common use of infrastructure between passengers and freight transportation entails the difficulty of the distribution of each impact between each type of transport. For rail infrastructure, allocation between passenger and goods transportation is unavoidable (Spielmann and Scholz, 2005).

\begin{tabular}{|c|c|c|c|c|}
\hline \multirow{9}{*}{$\begin{array}{l}\text { Life Cycle } \\
\text { Inventory for } \\
\text { rail transport }\end{array}$} & \multirow{2}{*}{ Rail Operation } & \multicolumn{2}{|c|}{ Energy consumption } & \\
\hline & & \multicolumn{2}{|c|}{ Direct emissions } & \\
\hline & \multirow{2}{*}{$\begin{array}{c}\text { Rail } \\
\text { Equipment }\end{array}$} & \multicolumn{2}{|c|}{ Locomotives and railcars } & \\
\hline & & \multicolumn{2}{|c|}{ Goods transport wagons } & \\
\hline & \multirow{5}{*}{$\begin{array}{c}\text { Rail } \\
\text { Infrastructure }\end{array}$} & \multirow[t]{2}{*}{$\begin{array}{c}\text { Railway } \\
\text { track system }\end{array}$} & $\begin{array}{l}\text { Railway } \\
\text { track }\end{array}$ & $\begin{array}{l}\text { - Rail } \\
\text { - Sleeper } \\
\text { - Fastening system } \\
\text { - Elastomeric pads } \\
\text { - Ballast } \\
\text { - Base } \\
\text { - Sub-base } \\
\text { - Geosynthetics material }\end{array}$ \\
\hline & & & $\begin{array}{l}\text { Railway } \\
\text { track } \\
\text { foundation }\end{array}$ & $\begin{array}{l}\text { - General groundwork } \\
\text { - Track foundation work } \\
\text { - Noise protection } \\
\text { - Other track structures }\end{array}$ \\
\hline & & \multicolumn{2}{|c|}{ Railway bridges } & $\begin{array}{l}\text { - General groundwork } \\
\text { - Railway track (rail, sleeper, fastening } \\
\text { systems, elastomeric pads and ballast) } \\
\text { - Noise protection } \\
\text { - Construction of a concrete bridge } \\
\text { - Construction of a steel bridge }\end{array}$ \\
\hline & & \multicolumn{2}{|c|}{ Railway tunnels } & $\begin{array}{l}\text { - General groundwork } \\
\text { - Tunnel work } \\
\text { - Other tunnel structures }\end{array}$ \\
\hline & & \multicolumn{2}{|c|}{$\begin{array}{c}\text { Railway electrical } \\
\text { equipment }\end{array}$} & $\begin{array}{l}\text { - General groundwork } \\
\text { - Electric power supply } \\
\text { - Telecommunication } \\
\text { - Signal \& Communication }\end{array}$ \\
\hline
\end{tabular}

Table 1 : Life Cycle Inventory for rail transport. Source: Own elaboration based on Spielmann et al., 2007; The SMARTrail Consortium, 2014 and Stripple and Uppenberg, 2010 
The Life Cycle Inventory (LCI) for railway track is based on the EU FP7 SMARTrail project (The SMARTrail Consortium, 2014). The LCI for railway track is divided in 8 stages, each related with one of the materials/products of the railway track: rail, sleeper, fastening system, elastomeric pads, ballast, base, sub-base and geosysnthetics material.

The LCI for railway track foundation is based on the EPD UN CPC 53212 for railway track foundations on the Bothnia Line and the related report of Stripple and Uppenberg, 2010. The LCI for railway track foundation is divided in 4 stages: General groundwork, track foundation work, noise protection and other track structure.

2.3.1. Life Cycle Inventory for railway bridges

The Life Cycle Inventory (LCI) for railway bridges is based on the EU FP7 SMARTrail project (The SMARTrail Consortium, 2014 ), the EPD UN CPC 53212 for railway bridges on the Bothnia Line and the related report of Stripple and Uppenberg, 2010. The LCI for railway bridges is divided in 5 stages, each related with one of the stage of construction of the railway bridge: general groundwork, railway track system, application of noise protection, construction of a concrete bridge and construction of a steel bridge.

2.3.2. Life Cycle Inventory for railway tunnels

The Life Cycle Inventory (LCI) for railway tunnels is based on the EPD UN CPC 53212 for railway tunnels on the Bothnia Line and the related report of Stripple and Uppenberg, 2010. The LCI for railway tunnels is divided in 3 stages: general groundwork, tunnel work and other tunnel structure.

2.3.3. Life cycle Inventory for electrical installations in railway

The Life Cycle Inventory (LCI) for electrical installations in railway is based on the EPD UN CPC 53212 for power, signalling and telecom system on the Bothnia Line and the related report of Stripple and Uppenberg, 2010. The LCI for electrical installations in railway is divided in 4 stages: general groundwork, electric power supply, telecommunication and signal and communication.

\subsection{New impact categories}

The use of LCA method in the transport sector shows its methodological limitations. Indeed, significant and relevant environmental impacts such as those related to accidents damages, noise impact and land use planning, are not adequately measured using the current LCA methodology. Therefore, to achieve the objectives of the study, it is required to improve the current methodology with the development and harmonization of new impact categories relative to accidents damages (Fries and Hellweg, 2014), noise impact (Althaus et al., 2009 and Cucurachi et al., 2012) and land use planning (Koellner et al., 2013) for impact assessment.

\subsection{External cost}

Willingness of Europe to promote intermodal transportation by internalization of external costs is the last opportunity addressed in this field. In order to complete the environmental impact assessment of rail freight intermodality in Belgium, a study of external costs will be considered.

The negative external costs of transport are not usually assumed by transport users and hence not taken into account when they decide to use transportation. The internalisation of external costs by transport users could be used for mitigate the negative effects of transport (RICARDO AEA, 2014). In rail transport, internalisation of negative external costs is not as developed as for road transport. The most important negative externalities are the direct air emissions, noise, water pollution, congestion, accidents and land use by the infrastructure (Demir et al., 2015). 


\section{Conclusion}

The results obtained in this study could help in making optimised policy decisions relative to the development of intermodal transportation in Belgium including environmental aspects and allowing the pollution reduction of direct emissions. Moreover, environmental impacts (including effects on human health and ecosystems) and negative external cost will be a criterion to help in decision-making concerning future developments for rail transportation.

The combination between the LCA approach and monetization of impacts will allow obtaining a precise analysis of external costs of rail transport (RICARDO AEA, 2014), and then provide information to promote this intermodal transportation. Moreover, a comparison between the most plausible scenarios of rail, road, inland waterways freight transport or combinations of them will be made.

The results also improve the accuracy of transport databases and potentially improve the environmental impact of transport. Results will highlight clues of improvement in terms of rail transportation for several impact categories in e.g. climate change, ecotoxicity, acidification or human toxicity (cancer and non-cancer related).

\section{$\underline{\text { Acknowledgement }}$}

The researches underlying these results have been financed by the Belgian Science Policy under Contract No. [BR/132/A4/BRAIN-TRAINS].

\section{Bibliography}

Althaus H.J., de Haan P. and Scholz R.W., Part 1: state-of-science and requirement profile for consistent context-sensitive integration of traffic noise in LCA, The International Journal of Life Cycle Assessment, Volume 14, pp. 560-570, 2009

Crozet Y., Haucap J., Pagel B., Musso A., Piccioni C., Van de Voorde E., Vanelslander T. and Woodburn A., Development of rail freight in Europe: What regulation can and cannot do. CERRE policy paper. Centre on Regulation in Europe (CERRE), 2014

Cucurachi S., Heijungs R. and Ohlau K., Towards a general framework for including noise impacts in LCA. The International Journal of Life Cycle Assessment, Volume 17, pp. 471487, 2012

Demir E., Huang Y., Scholts S. and Van Woensel T., A selected review on the negative externalities of the freight transportation: Modelling and pricing. Transportation Research Part E: Logistics and Transportation Review, Volume 77, pp. 95-114, 2015

European Environment Agency, Climate for a transport change. TERM 2007: indicators tracking transport and environment in the European Union. Office for Official Publications of the European Communities, Luxembourg, 2008

Environmental Product Declaration (EPD) UN CPC 53212 for power, signalling and telecom systems on the Bothnia Line, Botniabanan AB, 2010

Environmental Product Declaration (EPD) UN CPC 53212 for railway bridges on the Bothnia Line, Botniabanan AB, 2010

Environmental Product Declaration (EPD) UN CPC 53212 for railway track foundations on the Bothnia Line, Botniabanan AB, 2010

Environmental Product Declaration (EPD) UN CPC 53212 for railway tunnels on the Bothnia Line, Botniabanan AB, 2010

EUROSTAT, Eurostat Statistics, viewed March 24, 2015, http://ec.europa.eu/eurostat/data/database

European Commission - Joint Research Centre - Institute for Environment and Sustainability, International Reference Life Cycle Data System (ILCD) Handbook - General guide for 
Life Cycle Assessment - Detailed guidance. First edition March 2010. EUR 24708 EN. Publications Office of the European Union: Luxembourg, 2010

European Commission - Joint Research Centre - Institute for Environment and Sustainability, International Reference Life Cycle Data System (ILCD) Handbook- Recommendations for Life Cycle Impact Assessment in the European context. First edition November 2011. EUR 24571 EN. Publications Office of the European Union: Luxembourg, 2011

European Commission, White Paper on transport. Roadmap to a single European transport area - Towards a competitive and resource-efficient transport system. Directorate-General for Mobility and Transport, 2011

European Commission, EU transport in figures. Statistical Pocketbook 2014. Publications Office of the European Union, Luxembourg, 2014

European Commission, Infrastructure - TEN-T - Connecting Europe. Retrieved from http://ec.europa.eu/transport/themes/infrastructure/ten-t-guidelines/corridors/corridorstudies_en.htm, 2014b

European Parliament, The future of sustainable freight transport and logistic. Workshop "The future of transport". Directorate-General for internal policies. Policy department B: Structural and cohesion policies. Transport and Tourism, 2010

Facanha C. and Horvath A., Environmental assessment of freight transportation in the U.S. The International Journal of Life Cycle Assessment, Volume 11, Issue 4, pp. 229-239, 2006

Fries N. and Hellweg, S., LCA of land-based freight transportation: facilitating practical application and including accidents in LCIA. The International Journal of Life Cycle Assessment, Volume 19, pp. 546-557, 2014

Hendrikson C., Scott Matthews H. and Cicas G., Analysis of regional supply chain economic and environmental effects of expansion of the US freight rail system. Applications of Advanced Technology in Transportation, pp. 768-773, 2006

International Standardization Organization, ISO 14040: Management environnemental Analyse du cycle de vie - Principes et cadre. ISO, 2006

International Standardization Organization, ISO 14044: Management environnemental Analyse du cycle de vie - Exigences et lignes directrices. ISO, 2006

Koellner T., de Baan L., Brandão M., Milà i Canals L., Civit B., Margni M., Saad R., Maia de Souza D., Beck T. and Müller-Wenk R., UNEP-SETAC guideline on global land use impact assessment on biodiversity and ecosystem services in LCA. The International Journal of Life Cycle Assessment, Volume 18, Issue 6, pp. 1188-1202, 2013

Lammgård C., Intermodal train services: A business challenge and a measure for decarbonisation for logistic service providers. Research in Transportation Business \& Management, Volume 5, pp. 48-56, 2012

Mckinnon A., Browne M., Whiteing A. and Piecyk M., Green logistics: improving the environmental sustainability of logistics, Kogan Page, 2015

Reis V., Meier J.F., Pace G. and Palacin R., Rail and multi-modal transport. Research in Transportation Economics, Volume 41, pp. 17-30, 2013

RICARDO AEA, Update of the Handbook on External Costs of Transport. Final Report. Report for the European Commission: DG Mobility and and Transport, 2014

Spielmann M. and Scholz R.W., Life Cycle Inventories of Transport Services. Background data for freight transport. The International Journal of Life Cycle Assessment, Volume 10, Issue 1, pp. 85-94, 2005

Spielmann M., Bauer C., Dones R. and Tuchschmid M., Transport Services. Ecoinvent report No. 14. Swiss Centre for Life Cycle Inventories, Dübendorf, 2007

Stripple H. and Uppenberg S., Life cycle assessment of railways and rail transports Application in environmental product declarations (EPDs) for the Bothnia Line. IVL Swedish Environmental Research Institute, 2010 
The International EPD® System, Product Category Rules (PCR) 2013:19 Version 1.03 for railways UN CPC 53212. Valid until 2016-12-13, 2014

The SMARTrail Consortium, SMARTrail - Deliverable 4.3 Report on LCA and WLC models for aging rail networks. EU $7^{\text {th }}$ Framework Programme under call SST.2011.5.2-6 cost-effective improvement of rail transport, infrastructure. Grant agreement no: 285683, 2014

UNEP/SETAC Life Cycle Initiative, Global Guidance Principles for Life Cycle assessment Databases. A basis for greener processes and products. United Nations Environment Programme, 2011

Van de Voorde E. and Vanelslander T., Development of rail freight in Europe: What regulation can and cannot do. Belgium case study. Centre on Regulation in Europe (CERRE), 2014

Weidema B.P., Bauer C., Hischier R., Mutel C., Nemecek T., Reinhard J., Vadenbo C.O. and Wernet G., Overview and methodology. Data quality guideline for the ecoinvent database version 3. Ecoinvent Report 1(v3). St. Gallen: The ecoinvent Centre, 2013 